Шинкарук Василь Дмитрович

доктор фрілологічних наук, професор,

декан гуманітарно-педагогічного факультету

Національного університету біоресурсів

і природокористування України

ORCID 0000-0001-8589-4995

vashyn2010@ukr.net

Шинкарук Олександра Василівна

кандидат юридичних наук, доцент

кафедри міжнародних відносин та суспільних наук

Національного університету біоресурсів

і природокористування України

ORCID 0000-0002-5494-1370

aleksandra.shyn5@gmail.com

\title{
ШЕВЧЕНКОВА СПАДЩИНА - УНІКАЛЬНИЙ КУЛЬТУРНИЙ СКАРБ УКРАЇНСЬКОГО НАРОДУ
}

\begin{abstract}
Мета дослідження полягає у тому, щоб на основі аналізу опрацьованих джерел з позиції сучасної методології дослідити вплив постаті Тараса Шевченка на українське культуротворення та обгрунтувати вплив його творчої спадщини на культурно-освітнє життя українського народу.Методологія дослідження вироблена на основі відповідних методів зарубіжної та вітчизняної науки. Провідним $є$ структурно-наратологічний аналіз змісту і жанрової форми тексту. Для вивчення Шевченкової спадщини використано порівняльно-типологічний метод. Задля повного представлення розгляду особливостей творчого світовідчуття поета застосовано історикобіографрічний, історико-літературний і контекстуальний методи. Наукова новизна полягає в обгрунтуванні ролі Великого Кобзаря в українському культуротворенні; системно досліджено вплив концептів Бог, Україна, Свобода у творчій спадщині Великого Кобзаря на культурно-освітнє життя українського народу, розкрито значення творчої спадщини Великого Кобзаря в українському культуротворенні. Висновки. Теоретико-методологічні засади дослідження ґрунтуються на сучасних методах і принципах пізнання історичних явищ і процесів. Дослідження Шевченкової спадщини як унікального культурного скарбу українського народу потребує комплексного монографрічного дослідження. Постать Великого Кобзаря в українському культуротворенні є символом відродження національної самосвідомості. Саме Тарас Шевченко у своїй творчості сформулював ідеологію визволення українського народу та створив систему цінностей українського народу. Обгрунтовано вплив концептів Бог, Україна, Свобода у творчій спадщині Великого Кобзаря на культурно-освітнє життя українського народу.

Ключові слова: Тарас Шевченко, українське культуротворення; національні цінності, Бог, Україна, Свобода, творчість Великого Кобзаря, мова, культура, український народ.
\end{abstract}

Шинкарук Василий Дмитриевич, доктор фрилологических наук, профрессор, декан гуманитарнопедагогического фракультета Национального университета биоресурсов и природопользования Украины; Шинкарук Александра Васильевна, кандидат юридических наук, доцент кафедры международных отношений и общественных наук Национального университета биоресурсов и природопользования Украины

Наследие Тараса Шевченко - уникальное культурное сокровище украинского народа

Цель исследования заключается в том, чтобы на основе анализа проработанных источников с позиции современной методологии исследовать влияние фигуры Тараса Шевченко на украинское культурообразование и обосновать влияние его творческого наследства на культурно-просветительную жизнь украинского народа. Методология исследования выработана на основе соответствующих методов зарубежной и отечественной науки. Ведущим является структурно-наратологический анализ содержания и жанровой формы текста. Для изучения наследия Тараса Шевченко использован сравнительно-типологический метод. Ради полного представления рассмотрения особенностей творческого мироощущения поэта применены историко-биографический, историколитературный и контекстуальный методы. Научная новизна заключается в обосновании роли Большого Кобзаря в украинском культурообразовании; системно исследовано влияние концептов Бог, Украина, Свобода в творческом наследстве Большого Кобзаря на культурно-просветительную жизнь украинского народа, раскрыто значение творческого наследства Большого Кобзаря в украинском культурообразовании. Выводы. Теоретикометодологические принципы исследования основываются на современных методах и принципах познания исторических явлений и процессов. Исследование наследия Тараса Шевченко как уникального культурного сокровища украинского народа нуждается комплексного монографического исследования. Фигура Большого Кобзаря в украинском культурообразовании является символом возрождения национального самосознания. Именно Тарас Шевченко в своем творчестве сформулировал идеологию освобождения украинского народа и создал систему ценностей украинского народа. Обосновано влияние концептов Бог, Украина, Свобода в творческом наследстве Большого Кобзаря на культурно-просветительную жизнь украинского народа.

Ключевые слова: Тарас Шевченко, украинское культурообразование; национальные ценности, Бог, Украина, Свобода, творчество Большого Кобзаря, язык, культура, украинский народ

Shynkaruk Vasyl, Doctor of Philology, Professor, Dean of the Faculty of Humanities and Pedagogy of the

(С) Шинкарук В. Д., 2019

(С) Шинкарук О. В., 2019 
National University of Life and Environmental Sciences of Ukraine; Shynkaruk Oleksandra Vasylivna, PhD in Law, Associate Professor of the Department of International Relations and Social Sciences of the National University of Life and Environmental Sciences of Ukraine

Taras Shevchenko's heritage is a unique cultural treasure of the Ukrainians

The purpose of the article is to analyze the influence of Taras Shevchenko's personality on the Ukrainian cultural creation. It is based on the analysis of the reputable sources from the perspective of a modern methodology. It proves the influence of the concepts God, Ukraine, Freedom in the Great Kobzar's creative heritage on the cultural and educational life of the Ukrainians. The methodology is based on the proper methods of foreign and national sciences. The primary method is a structural and narrative analysis of the content and genre form of the text. A comparative typological method is also used to study Taras Shevchenko's heritage. Historical-biographical, historical-literary, and contextual methods are used for a complete presentation of the poet's creative worldview. Scientific novelty deals with the study of the Great Kobzar's role in the Ukrainian cultural creation, the influence of the concepts God, Ukraine, Freedom in the Great Kobzar's creative heritage on the cultural and educational life of the Ukrainians. The data is systematically studied. The significance of the Great Kobzar's creative heritage in Ukrainian cultural creation is emphasized. Conclusion. Theoretical and methodological aspects of the research are based on the contemporary methods and principles of cognition of historical phenomena and processes. The study of Shevchenko's heritage as a unique cultural treasure of the Ukrainians should be developed into a comprehensive monographic study. The Great Kobzar's figure $\mathrm{n}$ the Ukrainian cultural creation is a symbol of the revival of national identity. It was Taras Shevchenko who formulated the ideology of the Ukrainians' freedom in his works and created the system of values. The influence of the concepts God, Ukraine, Freedom in the Great Kobzar's creative heritage on the cultural and educational life of the Ukrainians is highlighted in detail.

Key words: Taras Shevchenko, Ukrainian cultural creation, national values, God, Ukraine, Freedom, the Great Kobzar's creativity, language, culture, the Ukrainians.

Актуальність теми дослідження. У культурному житті України вже два століття беззаперечною постаттю є Тарас Шевченко. Його творча спадщина є унікальним культурним скарбом українського народу, а «Кобзар» - головна визитівка України, що прославила українську культуру в усьому світі. Значущість обраної теми дослідження зумовлена потребою наукового осмислення спадщини Великого Кобзаря з позицій сьогодення.

Великий Кобзар у своїй творчій спадщині втілив образ української нації, українського народу та обличчя своєї епохи. У його творчості представлений широкий спектр моральних і духовних цінностей. Особлива увага у спадщині геніального митця надається національним цінностям, а саме ідеї Бога, України, Свободи, що належать до центральних проблем творчості поета. Вітчизняна наука потребує ще наукових досліджень, у яких концепти Бог, Україна, Свобода у творчості Тараса Шевченка розглядалися б комплексно з погляду загальнолюдських цінностей. Особливо актуальною ця проблема є на початку XXI ст. і новим підходом суттєво відрізняється від попередніх.

Аналіз досліджень і публікацій. Творча спадщина Тараса Шевченка у різні часи була предметом дослідження. Зокрема досліджували, І. Айзеншток, Я. Славутич, Т. Масенко, Г. Честахіський, І. Дуда, П. Зайцев, П. Коваленко, М. Чалий, О. Навроцький, М. Максимович, М.Старицький та ін. Грунтовні шевченкознавчі праці та літературні твори, авторами яких були П. Жура, П. Филипович, С. Єфремов, К. Арабажин, Д. Красицький та ін.

У роки незалежності України вітчизняна наука суттєво поповнилася доробками відомих діячів української культури та науковців з вивчення творчої спадщини Тараса Шевченка. Зокрема, В.Пахаренка "Незбагнений апостол. Нарис світобачення Т. Шевченка", В. Поліщука “Повісті Т. Г. Шевченка і розвиток повістевого жанру в українській літературі", М. Жулинського “Із забуття - в безсмертя (Сторінки призабутої спадщини)".

У шевченкознавстві порушувалися питання Бога, України, Свободи у творчості Великого Кобзаря, але й нині є потреба в ґрунтовних працях, присвячених комплексному дослідженню цих концептів. Чимало вітчизняних науковців досліджували цю проблему в своїх накових доробках, а саме І. Огієнко "Релігійність Тараса Шевченка", .А. Колодний “Бог і Шевченківська людина”, Д. Степовик "Наслідуючи Христа”, Л. Генералюк “Святим дивом сяють храми Божі...". Храми України в малярстві, поезії, прозі Шевченка”, Р. Іваничук “Співець свободи”, Л. Тарнашинська “Поет духовної свободи”, О. Орлик “Апостол правди і свободи”, О. Забужко “Шевченків міф України” та ін.

Досліджуючи концепти Бог, Україна, Свобода, науковці відзначали любов Тараса Шевченка до України, прагнення волі для українського народу, зосереджували увагу на окремих аспектах проблеми, але не вдаючись безпосередньо до комплексного аналізу цієї проблематики.

Мета статті - дослідити роль постаті Тараса Шевченка в українському культуротворенні та обгрунтувати вплив концептів Бог, Україна, Свобода у творчій спадщині Великого Кобзаря на культурноосвітнє життя українського народу.

Виклад основного матеріалу. Тарас Шевченко - феномен не тільки у вітчизняній, але й світовій культурі. Президент США Ліндон Джонсон писав, що “Шевченко цілком заслуговує на почесті, якими оточується. Він був більше, ніж українець - він був державним мужем і громадянином світу. Він був більше, ніж поет - він був хоробрим воїном за права і волю людей..." [3,14]. Слова 36 президента США Ліндона Джонсона підтверджують, що творча спадщина Тараса Шевченка - це надбання не лише української культури, а й світової. Своєю поезією Великий Кобзар прославив Україну, її духовність і 
народ. “Кобзар” Тараса Шевченка повністю перекладено 6 мовами - російською, англійською, польською, казахською, киргизькою і румунською. Низку творів Великого Кобзаря перекладено понад 100 мовами, а "Заповіт" Шевченка перекладено понад 150 мовами світу.

Зі своєю поезією Тарас Шевченко з'явився в той час, коли Україна була поділена між Російською та Австрійською імперіями і нашому народові загрожувало розчинення в інших націях. "Досить було однієї людини, - писав Остап Вишня про Великого Кобзаря, - щоб урятувати цілий народ, цілу націю" [10, 9].

До Тараса Шевченка у творчості його попередників П. Гулака-Артемовського, Є. Гребінки, Г. Квітки-Основ'яненка та інших творців як такого не було народу (українського), а вживались слова земляк, земляки, наші люди. Л. Білецький відзначає, що "від самих початків Шевченкової творчості поет задав собі ясну справу, що Україна - окремий і вповні географічно, етнографічно, звичаєво і взагалі духовно самостійний край. У Шевченка тільки не було тих відповідних термінів для означення нарід і нація, якими ми тепер послуговуємось і їх розрізняємо"[1, 330]. О. Похльовська зауважує, що у творчій спадщині Тараса Шевченка віками принижувана людина вперше ступила на кін культури як суб'єкт історії [8, 21].

Перед Тарасом Шевченком було завдання - вказати шлях виведення рідного народу з неволі, тому своєю поезією поет довів, що свобода - найбільший скарб людини. Творчість Великого Кобзаря відтворила національні цінності: Бог, Україна, Свобода, які за цілі тисячоліття оспівані українським народом і на яких тримається віками буття української нації.

Тарас Шевченко усе своє життя перебував у духовному пошуку правди за Україну, за український народ, за свободу. І в поезії, і в листах, і в щоденнику зустрічаємо безліч вказівок на те, що Тарас Григорович молився до Бога. “Молюся! Господи, молюсь! Тебе хвалить не перестану!” [10].

Геній Великого Кобзаря - це уміння духовними фарбами тонко змалювати Бога і Україну. Іван Огієнко, досліджуючи творчість Тараса Шевченка, писав, що “...коли зібрати докупи все, що становить історію релігійного стилю “Кобзаря”, то все це складає близько 15 відсотків усього “Кобзаря.” Шевченко неповторний у нашій літературі таким широким релігійним виявленням!” [7, 173]. Усе життя в “Кобзарі", релігійне й церковне, - усе описане з погляду віруючого християнина. Автор думає про Бога невпинно, згадує його постійно, нагадує про нього завжди. Бог - головний двигун життя в “Кобзарі”, головний предмет усього [2, 172].

Власне у назвах поезій Великого Кобзаря спостерігаємо біблійний зміст, зокрема, “Подражаніє Ієзекілію. Глава 19”, “Ісаія. Глава 35”, “Осія. Глава 14”, “Подражаніє 11 псалму”, “Давидові псалми», "Царі”, “Неофіти”, “Тризна”, а також зустрічаємо досить відверту релігійність: “Боже, спаси, суди мене Ти по своїй волі” (“Давидові псалми”) та “до самого Бога молитися” (“Заповіт”) та ін.

У поезії найтісніше переплітається з релігійністю поета тема України. Віра в Бога, молитва за Україну, молитва за народ, то велика сила, яка підняла малоросів у 1917 році на боротьбу за незалежність України, яка озброїла волинську молодь проти двох світових потуг у 1943-му, яка підняла молодь на Майдані, хлопців за Донецький аеропорт. Рядки поезії Великого Кобзаря, натхненно повторені першим героєм "Небесної сотні" Сергієм Нігояном, облетіли цілий світ і переконливо показали істинний дороговказ Тараса Шевченка - віра в Бога, Україну, Свободу. “Борітеся - поборете, Вам Бог помагає! За вас правда, за вас слава І воля святая!".

У своєму чесному служінні народові Шевченко і сьогодні разом з нами. Із його поезії “постає реальна, жива людина з великим серцем, яка своє стражденне життя поклала на вівтар України [4, 92].

Важкий шлях Шевченка до творчих висот в образній фрормі відобразив Іван Франко: “Він був сином мужика і став володарем у царстві духа. Він був кріпаком і став велетнем у царстві людської культури. Він був самоуком і вказав нові, свіжі і вільні шляхи професорам та книжним ученим" [9, 255]. Також Іван Франко у науковому доробку "Вступ до Докторської дисертації “Політична поезія Шевченка 1844-1847" зауважує, що поет посідає "не оспоримо перше місце, i, доки тривати буде українське слово, Шевченко неперестане вважатися головою і завершенням одної многозначучої доби нашої літератури" [9, 244].

Погляди Тараса Шевченка на засади існування української нації, яка має право на самовизначення $є$ актуальними, оскільки Україна протягом століть перебувала під жорстокою політикою окупантів. Українська нація 350 років була колоніями різних держав, а у часи Великого Кобзаря особливо гостро ця потреба відчувалась, оскільки Україна перебувала під владою Російської імперії, де особливе було засилля русифікації українського народу.

“Феноменальна роль Шевченка [полягає в тому], що український поет могутньо і всебічно виразив своєю творчістю духовність українців, ідеали і прагнення, він в такій мірі став символом своєї країни, як Гомер був виразом всієї Еллади, Вергілій - Римської імперії. Шевченко став духовним провідником, виразником усіх основних національних стремлінь" [2, 11].

Значним виявом служіння національній ідеї $\epsilon$ участь Тараса Шевченка в КирилоМефодіївському товаристві (1845-1847). “Проблема політичного ідеалу Т. Шевченка залишається актуальною і для сучасної науки. Кращому її розумінню сприяє з'ясування способів досягнення бажаного соціально- політичного майбутнього України. У радянському шевченкознавстві традиційно наголошу- 
валося на прихильності поета до революційних, насильницьких методів руйнування « імперії зла « та створення справедливого суспільства. Самого Т. Шевченка називали «співцем селянської революції «для якої необхідно « обух сталить та добре вигострить сокиру" $[6,88]$.

Національна ідея є визначальною для творчості Тараса Шевченка і наскрізно проходить, починаючи від ранньої поезії і завершуючи передсмертною фрілософічною лірикою. Поема “І мертвим і живим, і ненарожденним землякам моїм в Україні і не в Україні моє дружнєє посланіє” засвідчує пророче розуміння Шевченком української національної ідеї, самобутності України, її самодостатності. Висловлення "В своїй хаті своя правда, і сила, і воля" - це пророче розуміння Шевченком української національної ідеї.

Велич України він вбачав у величі рідного слова, у величі української культури. Великого Кобзаря турбувало, що українці відрікаються від неньки-України, нехтуючи своєю рідною мовою, культурою і прагнув залучити український народ до глибокого вивчення своєї історії: “...та й спитайте Тоді себе: що ми? Чиї сини? яких батьків? Ким? за що закуті?”. Слова геніального поета були пророчими, адже неповага до рідної мови відчуваються й у сьогоднішній Україні. Саме політичний зміст Шевченкового слова зробив його національним пророком і має для нас велике значення.

Яскравим виявом національної ідеї є поезія "У неділеньку святую”, в якій ідеал незалежної України асоціюється з демократично обраною владою, із громадською злагодою, єдністю у рішеннях та ідеях. Поет захоплюється одностайністю сільської громади. Своєрідний діалог Тараса Шевченка із Богом за Україну, за українську людину у поезії “Три літа” засвідчує, що Великий Кобзар бачив свою долю як національного пророка.

Ми впевнено сьогодні констатуємо, що Великий Кобзар - творець української національної ідеї,. символ великої любові до української культури.. Шевченкове слово запалювало патріотичним вогнем серця мільйонів, його творчість вивела із забуття українську націю, прославила українську культуру на весь світ. У листі до брата Микити він писав: “Микито, рідний брате!... Та, будь ласкав, напиши до мене так як до тебе пишу, не по-московському, а по нашому...Так нехай же я хоч через папір почую рідне слово, нехай хоч раз поплачу веселими сльозами, бо мені тут так стало скушно, що я всяку ніч тілько й бачу у сні, що тебе, Кирилівку, та ридаю, та бур'яни (ті бур'яни, що колись ховався од школи). Весело стане, прокинусь, заплачу... Ще раз прошу, напиши мені письмо, та по-своєму, будь ласкав, а не по-московському. Оставайся здоров. Не забудь же, зараз напиши письмо - та посвоєму" (1839, ноября 15 дня. С.-Петербург).

Епістолярій Тараса Шевченка спрямований на те, щоб розбудити українців, бо народ, який втрачає мову, приречений на забуття. Боротьба за українську мову - це боротьба за Українську державу.

Шевченкової правди, його пророцтв боявся московський режим. “Мій Боже милий, як то мало Святих людей на світі стало. Один на другого кують Кайдани в серці. А словами. Медоточивими устами Цілуються і часу ждуть...". Кожен з нас глибоко розуміє суть нинішніх не лише українськоросійських взаємин, а й відносин з іншими наддержавами, загрози для української незалежності.

Визначальною сутністю шевченківської фрілософії національної ідеї була й залишається ідея національної державності. Українська держава на всіх рівнях словом і ділом може захистити націю, створити потрібні умови для її процвітання. Тільки в Соборній Самостійній Український Державі може бути забезпечене національне існування.

Важливість творів Ведикого Кобзаря зростає, його велич з роками збільшується. Тарас Шевченко залишається незмінною та актуальною опорою української культури. Слушними $є$ слова $€$. Маланюка про Шевченка (правопис збережено): «Є якийсь величний символ і обітниця в тім, що його роковини припадають саме на час провесни, на дні, коли природа збуджується до життя, а мати-земля до творчости. І день його народження і день його скону ..., замикаються в одне коло, творять один замкнутий цикль - символ вічности» [5].

Висновки. Постать Тараса Шевченка посідає унікальне місце в українській культурі, а його творча спадщина є невичерпною скарбницею української нації, її духовності й культури. Феноменальність його творчості базується на трьох найосновніших національних ідеалах - Бог, Україна, Свобода, які визначають орієнтири культурно-освітнього життя українського народу. Збережемо українську мову, українську культуру і духовність - збережемо Україну як європейську державу, піднімемо в кожного українця дух національної свідомості.

Дослідження Шевченкової спадщини як унікального культурного скарбу українського народу потребує з позицій сьогодення комплексного монографічного дослідження. Постать Великого Кобзаря в українському культуротворенні $є$ символом відродження національної самосвідомості. Саме Тарас Шевченко у своїй творчості сформулював ідеологію визволення українського народу та створив систему цінностей українського народу. Концепти Бог, Україна, Свобода у творчій спадщині Великого Кобзаря мали і мають потужній вплив на культурно-освітнє життя українського народу.

\section{תimepamypa}

1. Білецький Л. Шевченко в його вболіванні за Україну "Русский мир" Кирила не для України: зб. наук. ст. / за ред. проф. А. Колодного. Київ: УАР, 2014.С. 318-341. 